\title{
Penerapan Model Pembelajaran Based Project untuk Meningkatkan Hasil Belajar Produk Kreatif dan Kewirausahaan Materi Desain Produk
}

\section{Eka Rismayawati*}

\author{
SMK N 1 Surabaya
}

\section{A R T I C L E I N F O}

Article history:

Received 12 December 2019

Received in revised form

01 January 2020

Accepted 30 January 2020

Available online 27

February 2020

\section{Kata Kunci:}

Hasil belajar, model

pembelajaran berbasis

project,Kewirausahaan

Keywords:

Learning outcomes,

project-based learning

models, Entrepreneurship

\begin{abstract}
A B S T R A K
Penelitian ini dlidasarkan pada pentingya belajar kewirausaaan dan bagaiman cara meningkatkan hasil belajar kewirausahaan siswa program studi pendidikan SMK. Berdasarkan hal tersebut tujuan penelitian ini adalah bagaimana cara meningkatan hasil belajar kewirausahaan siswa dengan model pembelajaran berbasis project di SMK N 1Surabaya. Metode yang digunakan dalam penelitian ini adalah penelitian tindakan kelas (PTK), dengan menggunakan empat langkah yaitu: 1) perencanaan (plan), 2) tindakan (act) 3).pengamatan (observe), 4) refleksi (reflect). Empat tahap tersebut dilakukan dengan dua siklus penelitian. Berdasarkan hasil penelitian selama dua siklus menunjukan, adanya peningkatan hasil belajar kewirausahaan dalam mebuat Desain Produkdan menyelesaikan soal yang diberikan kepada 32 siswa. Hasil analisis data selama siklus I dan II dapat disimpulkan: (1) siklus pertama jumlah siswa yang mempunyai kreatifitas berdasarkan observasi $70 \%$ yaitu sebanyak 19 siswa dan pada (2) siklus ke dua meningkat menjadi $90 \%$ yaitu sebanyak 25 siswa. Hasil belajar dari tes kewirausahaan siswa (1) siklus pertama jumlah siswa yang menjawab benar $70 \%$ yaitu sebanyak 22 siswa dan pada siklus ke dua (2) meningkat menjadi $92 \%$ yaitu sebanyak 26 siswa.
\end{abstract}

\section{A B S T R A C T}

This research based on the importance of entrepreneurship learning and how to improve student entrepreneurship learning outcomes in vocational education study programs. The purpose of this study is how to improve student entrepreneurship learning outcomes with a project-based learning model at SMK $N 1$ Surabaya. The method is classroom action research (CAR), with four steps: 1) planning, 2) action 3) observation, 4) reflection. The four stages are carried out with two research cycles. Based on the results of the study for two cycles, there was an increase in entrepreneurial learning outcomes in making Product Design and solving problems given to 32 students. The results of data analysis during the first and second cycles can be concluded: (1) the first cycle the number of students who have creativity based on observations of $70 \%$ ie $u$ as many as 19 students and in (2) the second cycle increased to $90 \%$ namely as many as 25 students. Learning outcomes from the student entrepreneurship test (1) the first cycle the number of students who answered correctly $70 \%$ is as many as 22 students and in the second cycle (2) increased to 92\%, as many as 26 students. 


\section{Pendahuluan}

Keberhasilan pendidikan tidak lepas dari proses belajar mengajar,yang di dalamnya meliputi beberapa komponen yang saling terkait antara lain guru,(pendidik),siswa ( peserta didik),materi (bahan),media ( alat/ sarana) dan metode pembelajaran atau pola penyampaian bahan ajar, Dalam proses belajar mengajar siswa mendapatkan sejumlah pengetahuan,nilai keteladanan yang membentuk sikap serta ketrampilan yang berguna baginya dalam menyikapi berbagai masalah kehidupan.Menurut syaiful Bahri Djamarah (2012:44-45) proses belajar mengajar di persekolahan didasari sebuah teori yang menyatakan bahwa " belajar pada hakekatnya adalah perubahan yang terjadi dalam diri seseorang setelah berakhirnya melakukan aktivitas belajar.

Sedangkan mengajar merupakan proses mengatur,mengorganisasi lingkungan yang ada di sekitar anak didik melakukan proses belajar. Selanjutnya,pada tahap berikutnya mengajar adalah proses memberikan bimbingan atau bantuan kepada anak didik dalam melakukan proses belajar ( Nana Sudjana dan Syaiful Bahri Djamarah,2012:45). Untuk itu guru dan siswa memiliki peran penting dalam mewujudkan proses belajar mengajar yang kondusif.

Proses belajar mengajar akan terorganisis dengan baik apabila terdapat kesiapan siswa dengan segala potensinya yang meliputi aspek kognitif,afektif,psikmotorik,juga guru yang mampu menciptakan suasana belajar yang mendukung pemberdayaan seluruh potensi yang di miliki siswa. Potensi anak didik perlu ditingkatkan melalui arahan dan bimbingan yang diberikan oleh guru di sekolah. Metode pembelajaran memegang peranan penting dalam rangkaian sistem pembelajaran. Untuk itu diperlukan kecerdasan dan kemahiran guru dalam memilih metode pembelajaran.Agar tujuan belajar baik secara kognitif,afektif maupun psikomotor dapat tercapai,maka metode pembelajaran diarahkan mencapai sasaran tersebut yaitu lebih banyak menekankan pembelajaran proses ( Sumiati dan Asra,2016:91). Metode pembelajaran menekankan pada proses belajar siswa secara aktif dalam upaya memperoleh kemampuan belajar.

Dalam proses pembelajaran,seorang guru berusaha dapat menciptakan dan menggunakan berbagai macam metode,agar pembelajaran tidak membosankan bagi siswa. Guru yang baik,menghargai setiap usaha yang dilakukan oleh siswa dan menghargai hasil kerja siswa,serta memberikan rangsangan atau dorongan kepada siswa supaya mampu berbuat dan berpikir,sambil menghasilkan karya dan pikiran kreatif, Oleh karenanya,seorang guru perlu menggunakan metode dan media pembelajarannyan yang bervariasi,seta menyediakan beragam pengalaman belajar melalui interaksi dengan isi atau materi pembelajaran.

Proses Pembelajaran yang menyenangkan merupakan salah satu faktor yang dapat menunjang keberhasilan suatu pembewlajaran .Ketika pembelajaran ini dilakukan dengan cara menyenangkan,maka materi-materi yang dipelajari akan mudah diterima dan dimengerti dengan baik oleh siswa. Agar dalam pembelajaran Produk Kreatif dan Kewirausahaan (PKK) tidak monoton dan lebih bervariasi,maka bisa diterapkan berbagai macam metode atau cara pembelajarannya yang di lakukan oleh guru sekali-sekali perlu di praktekkan. Tujuannya dari penggunaan metode maupun media pembelajaran yang bervarisi tersebut adalah bermanfaat untuk memperjelas penyampaian materi pelajaran dan untuk mengatasi keterbatasab guru dalam mengajar,disamping itu juga dapat diarahkan perhatian siswa agar lebih fokus pada materi pelajaran yang disamapikan.

Pembelajaran berbasis proyek merupakan pengorganisasian proses belajar yang dikaitkan dengan suatu objek konkret yang dapat ditinjau dari berbagai disiplin keilmuan atau mata pelajaran (BSNP, 2007:32). Menurut Djamarah dan Zain (2006:83) metode proyek adalah cara penyajian pelajaran yang bertitik tolak dari suatu masalah, kemudian dibahas dari berbagai segi yang berhubungan sehingga pemecahannya secara keseluruhan dan bermakna. Dalam proses pembelajaran, pemecahan suatu masalah tidaklah tuntas apabila hanya ditinjau dari satu disiplin ilmu saja, melainkan dipandang dari berbagai

disiplin ilmu atau mata pelajaran yang berkaitan dan memberikan sumbangsih terhadap penyelesaian masalah tersebut. Blumenfeld et al. (dalam Kamdi, 2008:4) mendeskripsikan model pembelajaran berbasis proyek (project based learning) berpusat pada proses relatif berjangka waktu, berfokus pada masalah, unit pembelajaran bermaknadengan mengintegrasikan konsep-konsepdari sejumlah komponen pengetahuan atau disiplin atau lapangan studi.

Bern dan Erickson (dalam Komalasari, 2010:70) menegaskan bahwa pembelajaran berbasis proyek (project-based learning) merupakan pendekatan yang memusat pada prinsip 12 dan konsep utama suatu disiplin, melibatkan siswa dalam memecahkan masalah dan tugas penuh makna lainnya, mendorong siswa untuk bekerja mandiri membangun pembelajaran, dan pada akhirnya menghasilkan karya nyata. Tidak semua kegiatan belajar aktif dan melibatkan proyek dapat disebut pembelajaran berbasis proyek. Oleh sebab itu, Thomas (dalam Kamdi, 2008:10) menyatakan terdapat 5 kriteria agar suatu pembelajaran 
dapat digolongkan dalam pembelajaran berbasis proyek, yaitu : Keterpusatasn (centrality), berfokus pada pertanyaan atau masalah, investigasi konstruktif atau desain, otonomi pebelajar, dan realisme.

Berdasarkan uraian diatas dapat disimpulkan bahwa dalam proses belajar mengajar,diharapkan adanya suasana pembelajaran yang dapat mengembangkan kemampuan siswa secara aktif. Namun pada proses pembelajaran berlangsung pada umumnya masih terpusat oleh guru (teacher centered). Dan bukan pada siswa (students Centered). Kondisi ini di pertegas pendapat yang disampaikan oleh Thomas Armstrong dalam bukunya" Sekolah Para Juara" juga mendiskripsikan model pembelajaran klasik yang antara lain memunculkan asumsi-asumsi : Pertama, para guru cendurung memisahkan atau memberikan identifikasi kepada para muridnya sebagai murid-murid yang pandai di satu sisi, dan murid-murid yang bodoh di sisi lain.Kedua suasana kelas cenderung monoton dan membosankan. Hal ini di karenakan para guru biasanya banyak bertumpu pada satu atau dua jenis kecerdasan dalam mengajar yaitu cerdas berbahasa dan cerdas berlogika.

\section{Metode}

Kegiatan yang dilakukan oleh peneliti pada tahap perencanaan adalah:

a. Peneliti melakukan analisis kurikulum untuk menentukan standar kompetensi dan kompetensi dasar yang disampaikan kepada siswa dengan menggunakan model pembelajaran berbased project.

b. Membuat RPP siklus I dengan model pembelajaran berbased project

c. Membuat lembar observasi siklus I untuk melihat bagaimana kondisi belajar mengajar dikelas ketika latihan dan kerja kelompok dilaksanakan.

d. Membuat Lembar Kerja Siswa siklus I

e. Membentuk kelompok yang bersifat heterogen baik dari segi kemampuan akademis, jenis pembelajaran dengan menggunakan model pembelajaran berbases project pada siklus I

f. Menyusun alat evaluasi pembelajaran berdasarkan perkembangan untuk dilaksanakan pada siklus II serta menyiapkan instrumen pendukung pembelajaran lainnya.

Dalam penelitian ini digunakan satu jenis instrumen penelitian sebagai alat pengumpulan data, yaitu: instrumen tes, yang terdiri atas: (a) Model Pembelajaran Berbased Project dan (b) tes hasil belajar siswa. Instrumen tes digunakan untuk mengukur variabel hasil belajar siswa. Instrumen tes ini berbentuk tes objektif pilihan ganda dengan 5 (lima) alternatif jawaban sebanyak 20 butir soal. Instrumen tes ini dikembangkan sendiri oleh peneliti. Instrumen tes dalam penelitian ini dibedakan menjadi dua, yaitu: instrumen pre-test dan post-test. Tujuannya untuk mengetahui kemampuan yang telah siswa miliki sebelum dan setelah mendapatkan perlakuan. Soal post-test dibuat sama dengan soal pre-test, tetapi dengan urutan nomor butir soal yang diubah.

\section{Hasil dan Pembahasan}

Data hasil pretes kelompok siswa sebelum mendapat perlakuan model pembelajaran berbased project, dianalisis dengan untuk mengetahui tingkat pengetahuan dan pemahaman tentang materi belajar yang berhubungan dengan desain produk.

Tabel 1. Hasil Belajar Siswa Pra Siklus

\begin{tabular}{lll}
\hline No. & Materi Ajar & Rata-rata \\
& & Nilai \\
\hline 1 & Kemasan produk & 69,00 \\
2 & Merancang kemasan produk & 69,85 \\
& Rata-rata nilai & 69,425 \\
\hline
\end{tabular}

Berdasarkan isi Tabel 1. terlihat bahwa nilai pretes kelompok siswa sebelum mendapat perlakuan pembelajaran dengan model pembelajaran berbased project adalah 69,425.

\section{Paparan Hasil Tindakan Siklus 1}

Perencanaan di mulai dengan membentuk kelompok diskusi. Siswa yang berjumlah 32 siswa dibagi menjadi 5 kelompok sehingga masing-masing kelompok berjumlah 7 siswa. Materi pelajaran yang diajarkan pada siklus I ini adalah pokok bahasan Desain Produk Proses pembelajaran ini menggunakan model berbased project yang diterapkan oleh guru secara langsung dalam pembelajaran di kelas.

Kegiatan yang dilakukan oleh peneliti pada tahap perencanaan adalah: 
g. Peneliti melakukan analisis kurikulum untuk menentukan standar kompetensi dan kompetensi dasar yang disampaikan kepada siswa dengan menggunakan pembelajaran dengan model pembelajaran berbasid project membuat RPP siklus I dengan model pembelajaran berbased project

h. Membuat lembar observasi siklus I untuk melihat bagaimana kondisi belajar mengajar dikelas ketika latihan dan kerja kelompok dilaksanakan.

i. Membuat Lembar Kerja Siswa siklus I

j. Membentuk kelompok (terdiri dari 5 siswa) yang bersifat heterogen baik dari segi kemampuan akademis, jenis pembelajaran dengan berbased project pada siklus I

k. Menyusun alat evaluasi pembelajaran berdasarkan perkembangan pada siklus II serta menyiapkan instrumen pendukung pembelajaran lainnya.

\section{A. Pelaksanaan Tindakan Siklus 1}

Pelaksanaan kegiatan belajar mengajar pembelajaran dengan model berbased project untuk siklus I dengan jumlah siswa 32 siswa. Dalam hal ini Peneliti bertindak sebagai guru. Pengamatan (observasi) dilaksanakan bersamaan dengan pelaksanaan pembelajaran. Pelaksanaan tindakan siklus I dapat diuraikan sebagai berikut:

a. Guru mengawali pembelajaran dengan mengucapkan salam dan menanyakan jumlah siswa yang hadir.

b. Guru melaksanakan apersepsi.

c. Guru membagi siswa dalam kelompok diskusi, kemudian memberi tugas yang berkaitan dengan penggunaan model pembelajaran berbased Project

d. Guru memberi tugas kepada siswa untuk mempresentasikan di depan kelas hal-hal yang berkaitan desain produk penggunaan model pembelajaran berbased project, waktu untuk presentasi adalah 3 menit untuk masing-masing kelompok.

e. Guru menindak lanjuti pembelajaran itu dengan menerangkan materi pelajaran tentang hal-hal yang berkaitan dengan Desain Produk menggunakan model pembelajaran berbased project waktu yang digunakan selama 10 menit.

f. Guru bersama-sama siswa mendemonstrasikan penerapan model pembelajaran berbased project materi desain product selama 10 menit.

g. Guru bersama-sama siswa melukukan kegiatan diskusi materi peluang usaha

h. Guru memberikan tugas secara individu selama 15 menit

i. Guru menutup pelajaran dengan mengucapkan salam.

Dalam siklus pertama ini, berdasarkan catatan peneliti, siswa masih kurang dapat bekerja sama, kerja kelompok masih kurang dapat berjalan sebagaimana yang diharapkan, presentasi belum banyak mendapat perhatian/tanggapan dari pendengar (siswa dari kelompok lain).

B. Hasil Tindakan Siklus 1

Selama pembelajaran berlangsung dilakukan observasi untuk mengetahui pengaruh kegiatan pembelajaran dalam meningkatkan hasil belajar peluang usaha siswa dalam proses pembelajaran materi Desain Produk. Pada pembelajaran ini siswa yang masuk sebanyak 32 siswa.

Guru mengamati, ternyata pada setiap kelompok masih didapati siswa yang kurang memperhatikan pelajaran yang berkaitan dengan Desain Produk dan masih berbicara dengan teman didekatnya tentang hal-hal yang tidak berkaitan dengan materi pembelajaran. Melalui serangkaian pertanyaan yang disampaikan kepada siswa, sebagian diantaranya belum memahami dan bahkan tidak tau apa yang di diskusikan dalam kelompoknya.

Adapun hasil belajar siswa setelah kegiatan yang diberikan dalam Siklus I, dapat dilihat di berikut:

Tabel 2. Hasil Belajar Siswa dalam Siklus 1

\begin{tabular}{llll}
\hline NO & NAMA SISWA & NILAI & PREDIKAT \\
1 & Mei Andriyani & 80 & Tuntas \\
2 & Moch.Anas & 70 & Tuntas \\
3 & Moh. Yusuf Santoso & 70 & Tuntas \\
4 & Mohammad Aris Ferry & 80 & Tunas \\
5 & Mohamad Saufid & 60 & Belum tuntas \\
6 & Muhammad Badriawan Kemal Abdau & 60 & Belum tuntas \\
7 & Muhammad Fadly Rois & 70 & Tuntas \\
8 & Muhammad Khoirul Anam & 80 & Tuntas \\
9 & Muhammad Syahrul Izar & 50 & Belum tuntas \\
\hline
\end{tabular}




\begin{tabular}{llll}
\hline 10 & Nanda Adhasari & 60 & Belum tuntas \\
11 & Ni Luh Gede Putri Surya Dewi Windari & 70 & Tuntas \\
12 & Nur Faricha Novita Sari. & 70 & Tuntas \\
13 & Putri Citra Andini & 90 & Belum tuntas \\
14 & Putri Wulandari & 60 & Belum tuntas \\
15 & Rahayu Ningsih & 75 & Tuntas \\
16 & Rica Ayu Dewi Lestari & 70 & Tuntas \\
17 & Ricky Alexander Anggriawan & 60 & Belum tuntas \\
18 & Rinda Rismayanti & 80 & Tuntas \\
19 & Ririn Dwiyanti & 60 & Belum tuntas \\
20 & Rizal Ramadhani & 90 & Tuntas \\
21 & Rizki Wahyudi & 80 & Tuntas \\
22 & Rossi Melania & 60 & Belum tuntas \\
23 & Salsabila Himmah & 60 & Belum tuntas \\
24 & Sandi Cristian Widyantoro & 80 & Tuntas \\
25 & Septian Dwi Cahyo & 60 & Belum tuntas \\
26 & Siti Marita Mispa Dewi & 80 & Tuntas \\
27 & Sugik & 60 & Belum tuntas \\
28 & Suhardiman Firdaus & 70 & Tuntas \\
29 & Susanti Meilia & 80 & Tuntas \\
30 & Triya Vina Agustin & 70 & Tuntas \\
31 & Widya Suciati & 80 & Tuntas \\
32 & Zefanya Anggela Carla Estrada & 70 & Tuntas \\
& Jumlah & 2400 & \\
& Rata-rata & 70.28 & \\
\hline & & & \\
\hline
\end{tabular}

Dari tabel di atas dapat diketahui bahwa dengan menerapkan pembelajaran pendekatan pembelajaran pemberian reward tampak bahwa nilai rata-rata siswa adalah 70,28 dengan nilai terendah 5 dan nilai tertinggi 9. Nilai ketuntasan belajar adalah 7,0 jumlah siswa yang mendapat nilai $\geq 7,0$ sebanyak 21 siswa, yang berarti $60 \%$ dari sejumlah 35 siswa memiliki nilai di atas taraf penguasaan konsep yang diberikan, lebih kecil dari persentase ketuntasan yang dikehendaki yaitu sebesar $95 \%$. Hal ini disebabkan karena siswa masih baru dan asing terhadap metode baru yang diterapkan dalam proses belajar mengajar. Sehingga dapat dikatakan siswa belum banyak memahami tentang konsep pokok bahasan yang dibahas.

C. Refleksi Tindakan Siklus 1

Dalam pelaksanaan kegiatan belajar mengajar pada siklus I yang masih terdapat kekurangankekurangan, Maka perlu adanya revisi untuk dilakukan pada siklus II antara lain :

a. Guru dalam memotifasi siswa hendaknya dapat membuat siswa lebih termotivasi selama proses belajar mengajar berlangsung.

b. Guru harus lebih dekat dengan siswa sehingga tidak ada perasaan takut dalam diri siswa, sehingga siswa lebih berkosentrasi dalam pembelajaran.

c. Guru harus lebih bersabar dalam membimbing siswa berdiskusi untuk menemukan hal-hal baru yang berkaitan dengan materi pembelajaran.

d. Guru secara intensif memberikan pengertian kepada siswa kondisi dalam berkelompok, kerjasama kelompok, dan keikutsertaan siswa dalam kelompok.

e. Guru mengubah jumlah siswa (dari 7 siswa menjadi 5 siswa) dalam satu kelompok.

f. Guru membantu kelompok yang belum memahami langkah-langkah model pembelajaran berbased project

g. Guru memberikan dorongan dan motivasi kepada siswa untuk lebih aktif mencari sumber belajar, diharapkan agar siswa memperoleh hasil yang diharapkan. 


\section{Paparan Hasil Tindakan Siklus II}

Perencanaan di mulai dengan membentuk kelompok diskusi. Siswa yang berjumlah 32 siswa dibagi menjadi 7 kelompok sehingga masing-masing kelompok berjumlah 5 siswa. Materi pelajaran yang diajarkan pada siklus II ini tetap pada pokok bahasan Desain Produk Proses pembelajaran pokok bahasan ini menggunakan model berbased project yang diterapkan oleh guru secara langsung dalam pembelajaran di kelas.

Kegiatan yang dilakukan oleh peneliti spada tahap perencanaan pada siklus II adalah:

a. Peneliti melakukan analisis kurikulum untuk menentukan Standar Kompetensi dan Kompetensi Dasar yang disampaikan kepada siswa dengan menggunakan model berbased project.Membuat RPP dengan model pembelajaran pendekatan pembelajaran berbased project siklus II

b. Membuat lembar observasi siklus II untuk melihat bagaimana kondisi belajar mengajar di kelas ketika latihan dan kerja kelompok dilaksanakan.

c. Membuat Lembar Kerja Siswa siklus II

d. Membentuk kelompok (terdiri dari 5 siswi) yang bersifat heterogen baik dari segi kemampuan akademis, model pembelajaran role playing pada siklus II

e. Menyusun alat evaluasi pembelajaran berdasarkan perkembangan pada siklus II serta menyiapkan instrumen pendukung pembelajaran lainnya

\section{Pelaksanaan Tindakan Siklus II}

Pelaksanaan kegiatan belajar mengajar dengan model pembelajaran berbased project untuk siklus II dilaksanakan di kelas XI PMRS1 SMKN 1 Dlanggu dengan jumlah siswa 32 siswi materi Desaian Produk. Dalam hal ini Peneliti bertindak sebagai guru. Pengamatan (observasi) dilaksanakan bersamaan dengan pelaksanaan pembelajaran. Pelaksanaan tindakan disesuaikan dengan RPP (Rencana Pelaksanaan Pembelajaran) dan lembar kerja yang telah dibuat dan mengacu pada revisi siklus I, sehingga kekurangankekurangan pada siklus I tidak terulang pada siklus II. Adapun proses belajar mengajar mengacu pada rencana pembelajaran yang telah dipersiapkan dengan menggunakan metode pembelajaranberbased project, dengan tahapan, presentasi kelas, kerja kelompok, tes individu,dan penghargaan kelompok.

Pelaksanaan tindakan siklus II dapat diuraikan sebagai berikut:

a. Guru mengawali pembelajaran dengan mengucapkan salam dan menanyakan jumlah siswa yang hadir.

b. Guru melaksanakan apersepsi.

c. Guru membagi siswa dalam kelompok diskusi, kemudian memberi tugas yang berkaitan dengan penggunaan model pembelajaran berbased project .Guru memberi tugas kepada siswa untuk mempresentasikan di depan kelas hal-hal yang berkaitan peluang usaha penggunaan model pembelajaran berbased project, waktu untuk presentasi adalah 3 menit untuk masing-masing kelompok.

d. Guru menindaklanjuti pembelajaran itu dengan menerangkan materi pelajaran tentang hal-hal yang berkaitan dengan peluang usaha menggunakan model pembelajaranberbased project, waktu yang digunakan selama 10 menit.

e. Guru bersama-sama siswa mendemonstrasikan penggunaan model pembelajaran berbased project materi peluang usaha selama 10 menit.

f. Guru bersama-sama siswa melukukan kegiatan kewirausahaan materi desain produk

g. Guru memberikan tugas secara individu selama 15 menit

h. Guru menutup pelajaran dengan mengucapkan salam.

A. Hasil Tindakan Siklus II

a. Selama pembelajaran berlangsung dilakukan observasi untuk mengetahui penerapan model reward dalam meningkatkan hasil belajar siswa dalam proses pembelajaran materi Desain Produk. Pada pembelajaran ini siswa yang masuk sebanyak 32 siswa.

b. Bila dilihat dari angka aktivitas guru dan siswa selama kegiatan belajar mengajar, maka secara keseluruhan aktivitas guru dan siswa menunjukkan pembelajaran yang berorientasi pendekatan keterampilan proses dalam setting pembelajaran pendekatan pembelajaran berbased project berpusat pada siswa, dimana siswa terlibat aktif dalam pembelajaran.

c. Pada akhir proses belajar mengajar siklus II siswa diberi tes dengan tujuan untuk mengetahui tingkat keberhasilan siswa dalam proses belajar mengajar yang sudah dilakukan di siklus I, kemudian dikomparasikan dengan hasil pada siklus II . 
d. Dalam pembelajaran siklus II, konsep-konsep yang teridentifikasi dikembangkan lebih lanjut. Dalam Siklus II ini, berdasarkan catatan peneliti, kerjasama siswa sudah berjalan dengan baik, sehingga masing-masing siswa dapat memecahkan masalah secara individual. Adapun data hasil tes pada siklus II adalah sebagai berikut:

Tabel 3. Nilai Tes Formatif Siswa dalam Siklus 2

\begin{tabular}{|c|c|c|c|}
\hline NO & NAMA SISWA & NILAI & PREDIKAT \\
\hline 1 & Mei Andriyani & 80 & Tuntas \\
\hline 2 & Moh.Farel Anas & 70 & Tuntas \\
\hline 3 & Moh.Yusuf Santoso & 80 & Tuntas \\
\hline 4 & Mohammad Aris Ferry Irawan & 90 & Tunas \\
\hline 5 & Mohammad Saufid & 80 & Tuntas \\
\hline 6 & Muhammad Badriawan Kemal Abdau & 80 & Tuntas \\
\hline 7 & Muhammad Fadli Rois & 80 & Tuntas \\
\hline 8 & Muhammad Khoirul Anam & 90 & Tuntas \\
\hline 9 & Muhammad Syarul Izar & 60 & Belum tuntas \\
\hline 10 & Nanda Adhasari & 90 & Tuntas \\
\hline 11 & Ni Luh Gede Putri Surya Dewi Windari & 80 & Tuntas \\
\hline 12 & Nur Farichah Novita Sari & 75 & Tuntas \\
\hline 13 & Putri Citra Andini & 70 & Tuntas \\
\hline 14 & Putri Wulandari & 90 & Tuntas \\
\hline 15 & Rahayu Ningsih & 80 & Tuntas \\
\hline 16 & Rica Ayu Dewi Lestari & 80 & Tuntas \\
\hline 17 & Ricky Alexander Anggriawan & 70 & Tuntas \\
\hline 18 & Rinda Rismayanti & 80 & Tuntas \\
\hline 19 & Ririn Dwiyanti & 90 & Tuntas \\
\hline 20 & Rizal Ramadhani & 80 & Tuntas \\
\hline 21 & Rizki wahyudi & 80 & Tuntas \\
\hline 22 & Rossi Melania Oktavia & 90 & Tuntas \\
\hline 23 & Salsabila Himmah & 60 & Belum Tuntas \\
\hline 24 & Sandy Christian Widyantoro & 90 & Tuntas \\
\hline 25 & Septiawan Dwi Cahyo & 80 & Tuntas \\
\hline 26 & Siti Marita Mispa Dewi & 80 & Tuntas \\
\hline 27 & Sugik & 80 & Tuntas \\
\hline 28 & Suhardiman Firdaus & 90 & Tuntas \\
\hline 29 & Susanti Meilia & 90 & Tuntas \\
\hline 30 & Triya Vina Agustin & 80 & Tuntas \\
\hline 31 & Widya Suciati & 79 & Tuntas \\
\hline \multirow[t]{3}{*}{32} & Zefanya Anggela Carla Estrada & 80 & Tuntas \\
\hline & Jumlah & 2814 & \\
\hline & Rata-rata & 80.4 & \\
\hline
\end{tabular}

Sumber Data : Hasil Ulangan Harian Siswa

Dari tabel di atas tampak bahwa hasil nilai evaluasi rata-rata siswa secara individual adalah 80,4 dengan nilai terendah 60 dan nilai tertinggi 90. Data diatas menunjukkan bahwa pada siklus II ini, nilai siswa secara individual mengalami peningkatan, yaitu siswa yang tuntas sebanyak 33 siswa dan yang belum tuntas sebanyak 2 siswa, yang berarti 95\% dari sejumlah 35 siswa memiliki nilai di atas taraf penguasaan konsep yang diberikan. Dari siklus 2 ini dapat dikatakan bahwa proses pembelajaran dengan model pembelajaran pendekatan pembelajaran berbased project dapat meningkatkan hasil belajar siswa. 


\section{B. Refleksi Tindakan Siklus II}

Dalam pelaksanaan kegiatan belajar mengajar pada siklus II ini masih terdapat kekurangankekurangan. Pada tahap ini akan merefleksikan kembali apa yang telah dilaksanakan selama penelitian tindakan kelas dilakukan. Dari data yang diperoleh dapat diuraikan sebagai berikut:

a. Selama proses belajar mengajar guru telah melaksanakan pembelajaran dengan cukup baik dengan model pembelajaran berbased project, meskipun ada beberapa bagian yang masih belum sempurna, tetapi presentasi pelaksanaan untuk masing-masing kegiatan sudah cukup baik.

b. Berdasarkan data hasil lembar observasi kegiatan kelompok siswa, diadakan perubahan jumlah kelompok pada siklus I sebanyak 7 siswa, dan pada siklus II sebanyak 5 siswa.

c. Kekurangan pada siklus I diperbaiki, sehingga pembelajaran menjadi lebih baik pada siklus II.

d. Hasil evaluasi siswa mengalami peningkatan dari siklus I ke siklus II, dan telah mencapai ketuntasan belajar pada siklus II ini sesuai yang diharapkan yakni peningkatan hasil belajar siswa.

Sebelum perlakuan diberikan pada masing-masing kelompok, nilai rerata pretes siswa sebelum diberi perlakuan pembelajaran dengan model berbased project adalah 69,425 . Setelah siswa diberi perlakuan pembelajaran dengan model berbased project pada siklus I mengalami peningkatan menjadi 70.28, namun hasil ini belum memenuhi target hasil belajar siswa mata pelajaran produk kreatif dan kewirausahaan yaitu 95\% .

Bila dihitung berdasarkan nilai rerata pretes, kelompok siswa yang diberi perlakuan pembelajaran dengan model pembelajaran berbased project. Setelah dilaksanaknnya siklus ke II mengalami peningkatan rerata hasil belajar sebesar 80,400-69,425 $=10,975$.

Berdasarkan hasil pada sisklus penelitian tersebut di atas, dapat ditunjukkan bahwa ada perbedaan hasil belajar desain produk antara siswa yang diajar menggunakan metode pembelajaran dengan dibantu model pembelajaran berbased project.

Hasil penelitian ini juga didukung oleh hasil penelitian Alma (2012) yang menyatakan bahwa ada perbedaan hasil belajar siswa yang yang mendapat perlakuan pembelajaran dengan model pembelajaran pemberian reward memperoleh rata-rata nilai sebesar 80,400, lebih tinggi daripada sebelum siswa diajar dengan model pembelajaran lainnya, yaitu 69,425

Penerapan pembelajaran dengan model pembelajaran berbased project memberikan peningkatatan yang lebih baik pada perolehan hasil belajar desain produk daripada penerapan pembelajaran dengan metode lainya. Dengan kata lain dapat diinterpretasikan bahwa penerapan pembelajaran dengan model berbased project dapat meningkatkan perolehan hasil belajar siswa pada materi desain produk daripada dengan model pembelajaran lain.

\section{Simpulan Dan Saran}

Penerapan pembelajaran dengan model berbased project memberikan peningkatatan yang lebih baik pada perolehan hasil belajar desain produk daripada penerapan pembelajaran dengan metode lainya. Dengan kata lain dapat diinterpretasikan bahwa penerapan pembelajaran dengan model berbased project dapat meningkatkan perolehan hasil belajar siswa pada materi desain produk daripada dengan model pembelajaran lainnya. Hal ini berdasarkan nilai rerata pretes dimana rata-rata hasil belajar siswa sebesar 69,425 , sedangkan setelah siswa diberi perlakuan pembelajaran dengan metode role playing setelah dilaksanaknnya siklus ke II mengalami peningkatan rerata hasil belajar sebesar 80,400 artinya terjadi peningkatan rerata hasil belajar siswa sebesar 10,975.

\section{Daftar Rujukan}

Arikunto, Suharsimi. 2018. Penelitian Tindakan Kelas. Jakarta: Bumi Aksara.

Arikunto. Suharsimi. 2014. Prosedur Penelitian suatu pendekatan praktik. PT. Rineka Cipta. Jakarta: PT. Asdi Mahasatya.

Aqib, Zainal, (2016). Penelitian Tindakan Kelas. Untuk : Guru. Bandung: Yrama Widia Departemen Pendidikan Nasional. 2014. Kamus Besar Bahasa Indonesia Pusat Bahasa Edisi Empat. Jakarta: Gramedia Pustaka

Djamarah, Syaiful Bahri. 2018. Psikologi Belajar. Jakarta: Rineka Cipta

Khodijah, Nyayu. 2014. Psikologi Pendidikan. Jakarta: PT Raja Grafindo Persada 
Mudjiono dan Damayanti. 2014. Belajar dan Pembelajaran. Jakarta. Rineka Cipta

Muliawan, Jasa Ungguh. 2016. 45 Model Pembelajaran Spektakuler. Yogyakarta: Ar-Ruzz Media

Muhibbin Syah. 2010. Psikologi Pendidikan Dengan Pendekatan Baru. Bandung: Remaja Rosdakarya.

Riduan. 2015. Belajar Mudah Penelitian Untuk Guru dan Karyawan dan Peneliti Pemula. Bandung: Alfabeta.

Sutama. 2010. Penelitian Tindakan Teori dan Praktek dalam PTK, PTS dan PTBK. Semarang: Citra Mandiri Utama.

Sutama. 2012. Metode Penelitian Pendidikan Kuantitatif, Kualitatif, PTK dan R \& D.Kartasura: Fairus Media.

Sadirman. 2011. Interaksi dan Msotivasi Belajar Mengajar. Jakarta: Rajawali Pers

Shoimin, Aris. 2014. 68 Model Pembelajaran Inovatif Dalam Kurikulum 2013. Yogyakarta: Ar-Ruzz Media.

Shoimin, Aris.2014. Kurikulum Program studi Pendidikan Akuntansi Univ. PGRI Palembang 